\title{
ANALISIS MODEL PEMBELAJARAN DARING KONSEP GETARAN DAN GELOMBANG PADA SISWA SMK DI MASA PANDEMI COVID-19
}

\author{
${ }^{1)}$ Agung Rahmadi \\ 1) SMKN 2 Tegalsari Banyuwangi \\ E-mail: $\underline{\text { agunxr@gmail.com }}$
}

\begin{abstract}
One of the efforts made by the government in the education sector is learning that is carried out without face to face or online learning to prevent the spread of Covid-19. This online learning model is a policy issued by the government for the sustainability of learning at all levels of education. SMK as an educational institution that creates work-ready graduates so that it demands a learning model that is able to develop the concept of student skills. In physics learning, especially related to vibrations and waves which were still considered difficult for students. This research aimed to analyze the online learning model of the concept of vibration and waves in vocational students during the Covid 19 pandemic. This research used a descriptive qualitative. Data is collected based on the results of a literature review such as books, journals, magazines, and articles. The results of this research showed that the online learning model that is applied still has various kinds of obstacles in the process, especially on vibration and wave material for vocational students who need a learning media to be able to increase students skills.
\end{abstract}

Key word: covid 19 pandemic, e-learning model, vocational high school

\section{PENDAHULUAN}

Pandemi Covid 19 saat ini tengah melanda dunia yang menyebar hampir ke seluruh negara sehingga Perserikatan Bangsa-Bangsa (PBB) menetapkan statusnya sebagai pandemik karena membidik manusia di seluruh dunia tanpa terkecuali Indonesia. Data terbarukan dari WHO pada tanggal 13 Juli 2021 sebanyak 223 negara telah terkonfirmasi terjangkit Covid 19 dengan total 188.080.023 jiwa dinyatakan terkonfirmasi positif dan total 4.055.871 jiwa dinyatakan meninggal dunia (WHO, 2021). Kasus di Indonesia berdasarkan data terbaharukan pada tanggal 13 Juli 2021 sebanyak 2.567.630 jiwa telah terkonfirmasi positif dan 67.355 jiwa dinyatakan meninggal dunia (Covid19.go.id, 2021).

Hal ini berdampak pada lumpuhnya sebagian besar kegiatan manusia pada berbagai sektor yang mengakibatkan gaya hidup masyarakat

berubah dan harus menyesuaikan dengan keadaan. Pemerintah Indonesia melakukan berbagai macam upaya untuk menekan penularan virus Covid 19 di semua sektor dan salah satu sektor yang menjadi fokus pemerintah adalah pendidikan. Pada sektor pendidikan, siswa tidak lagi melakukan pembelajaran tatap muka melainkan menggantinya menjadi pembelajaran daring atau e-learning dari berbagai jenjang sekolah mulai dari pendidikan dini hingga pendidikan tinggi. 
Kebijakan pemerintah dengan memberlakukan pembelajaran daring disebut sebagai suatu model pembelajaran jarak jauh yang pembelajarannya berbantuan internet untuk saling berinteraksi (Kasidi et al., 2020). Pembelajaran tanpa tatap muka merupakan model pembelajaran jarak jauh atau daring (Ramanta \& Widayanti, 2020). Selain untuk menekan penularan pandemik, kedepannya pembelajaran daring akan terus dilakukan sebagai salah satu tuntutan pendidikan abad 21 dan untuk menjaga proses keberlanjutan pembelajaran pada masa pandemik Covid 19 (Noviansyah \& Mujiono, 2021). Standar sekolah pada abad 21 atau abad digital adalah pembelajaran yang selalu berkaitan dengan teknologi untuk menghubungkan antara guru dan siswa (Eggen \& Kauchak, 2012). Pembelajaran daring ini juga akan menjawab tantangan dunia pendidikan yang berbasis teknologi digital pada era industri 4.0.

Era industri 4.0 merupakan suatu tantangan bagi dunia pendidikan untuk mampu beradaptasi dengan era teknologi digital. Kegiatan belajar mengajar mulai berubah ke era modern dengan sistem pembelajaran jarak jauh tanpa perlu melakukan tatap muka di sekolah. Pembelajaran tersebut dinamakan pembelajaran daring karena dilakukan dengan sistem jarak jauh dan membutuhkan internet sebagai penunjang pembelajaran. Pembelajaran daring bertujuan menjangkau ruang belajar yang luas dan lebih banyak pelajar yang menciptakan layanan pembelajaran bermutu (Sofyana \& Abdul, 2019).

Pembelajaran daring umumnya telah dilakukan di beberapa negara maju lainnya yang memanfaatkan akses internet sebagai media pembelajaran jarak jauh. Akan tetapi di Indonesia sendiri, pembelajaran jarak jauh baru dapat dilakukan beberapa tahun belakangan dikarenakan akses internet yang masih berpusat di kota sehingga pelajar yang masih tinggal di desa masih sulit untuk merasakan pembelajaran jarak jauh. Akan tetapi, pembelajaran daring diberlakukan hampir di seluruh Indonesia baik di kota maupun di daerah. Hal ini membuat ketimpangan antara siswa di daerah dengan di kota, karena sebagian besar siswa di daerah masih belum dapat menguasai teknologi maupun akses internet yang belum merata. Sedangkan hampir semua siswa di kota sudah terbiasa dengan akses internet.

Beberapa platform untuk menunjang kegiatan belajar mengajar secara daring mulai dari whatsapp, google classroom, dan zoom. Kemudian seiring dengan perkembangan teknologi dan situasi darurat pandemik ini, pemerintah melalui Kemendikbud memberikan akses gratis untuk 12 platform yang bisa diakses oleh siswa kapanpun sebagai penunjang kegiatan belajar mengajar di rumah. Tantangan dalam belajar daring bukan hanya pada siswa melainkan pendidik juga diharuskan untuk menguasai penggunaan teknologi digital ini. Karena guru jugalah yang akan mengajarkan kepada siswa, sedangkan platform hanya sebagai media guru dalam menyampaikan pembelajaran

Terdapat bermacam kendala ditemukan di lapangan pada saat pembelajaran daring. Hal ini dibuktikan dengan berbagai macam keluhan saat pembelajaran daring baik oleh siswa, guru maupun orang tua disebabkan oleh berbagai faktor. Keterbatasan menjadi faktor yang banyak dikeluhkan dimulai dari akses internet yang terbatas sampai dengan fasilitas teknologi yang kurang memadai, padahal pembelajaran daring sangat membutuhkan fasilitas perangkat mobile untuk akses informasi dimanapun dan kapanpun.

Sekolah Menengah Kejuruan (SMK) adalah lembaga pendidikan menengah yang dapat menciptakan lulusan yang siap terjun dalam dunia kerja (Suharno \& Widiastuti, 
2017). SMK menurut Peraturan Pemerintah Nomor 29 Tahun 1990 merupakan pendidikan menengah yang memfokuskan pengembangan kemampuan siswa pada suatu jenis pekerjaan. Karena pada siswa SMK pengajaran yang dilakukan bukan hanya mencangkup pengetahuan tetapi praktik dan keterampilan sehingga pengajar SMK di tuntut mampu memilah penggunaan teknologi agar dapat digunakan untuk pembelajaran.

SMK sebagai salah satu pendidikan menengah yang menciptakan siswa siap terjun dengan dunia kerja dengan Sumber Daya Manusia (SDM) yang siap kerja ini menunjukkan jika dalam hal penguasaan bukan hanya tentang ilmu pengetahuan melainkan keterampilan yang tinggi diiringi dengan etika dan karakter yang unggul. SDM yang seperti itulah yang harus diciptakan oleh lulusan SMK sehingga dapat menjadi generasi potensial. SMK harus mampu menyiapkan SDM yang produktif sesuai dengan keahlian kerja masing-masing pilihan bidangnya.

Sebagai lembaga formal, SMK mempunyai peran yang sangat penting karena lulusannya bukan hanya mampu dalam hal akademik saja melainkan mempunyai karakter yang unggul. Pengembangan keterampilan diutamakan pada SMK sebagai persiapan memasuki lapangan pekerjaan dengan professional. Bidang keterampilan yang dikembangkan di SMK disesuaikan dengan masing-masing jenis pekerjaan yang menjadi keunggulan siswa sehingga menciptakan SDM yang professional. Undang-Undang Nomor 20 Tahun 2003 menyatakan jika pendidikan kejuruan sebagai subsistem pendidikan yang khusus untuk membantu siswa dalam menyiapkan dirinya memasuki dunia lapangan kerja.

Siswa SMK akan lebih banyak mendapatkan pembelajaran keterampilan melalui praktik-praktik dibandingkan siswa
SMA yang fokus pembelajarannya pada bidang pengetahuan karena umumnya siswa SMA diperuntukkan untuk studi lanjut sedangkan siswa SMK dipersiapkan untuk siap di lapangan pekerjaan maka siswa SMK akan diasah kemampuannya sesuai dengan bidang keahliannya masing-masing.

Fisika merupakan salah satu ilmu pengetahuan sains yang memiliki keterkaitan langsung pada bidang teknologi (Pramuda \& Anggraeni, 2016). Kajian fisika yang mencangkup berbagai bidang teknologi seperti energi dan termodinamika, getaran dan gelombang, listrik dan magnet, astrofisika hingga struktur partikel kuantum menjadikan fisika berperan sangat besar pada pengembangan teknologi maupun industri. Salah satu materi pembelajaran fisika yaitu getaran dan gelombang sebagai suatu materi yang memiliki tantangan multikonsep sehingga memerlukan media pembelajaran yang mampu menyesuaikan. Konsep getaran dan gelombang yang berbasis teknologi membuat siswa mendapatkan pengalaman nyata tentang pembelajaran khususnya siswa SMK yang erat kaitannya dengan keterampilan. Sehingga memerlukan pembelajaran khusus yang mampu membuat siswa memahami konsep getaran dan gelombang walaupun dengan pembelajaran yang dilakukan melalui daring. Hal itu yang mendasari penelitian ini yang bertujuan untuk menganalisis model pembelajaran daring konsep getaran dan gelombang pada siswa SMK di masa pandemi Covid 19.

\section{METODE}

Penelitian ini menggunakan metode deskriptif kualitatif yang merupakan tata cara suatu penelitian yang menghasilkan data berupa deskriptif melalui kata-kata tertulis (Moleong, 2005). Kualitatif bertujuan menganalisis kualitas dari suatu penelitian. Jenis penelitian yang digunakan yaitu penelitian kepustakaan yang dilakukan 
dengan mengumpulkan berbagai informasi dan data dari berbagai sumber pustaka yaitu buku-buku, jurnal, makalah, ataupun karya tulis ilmiah yang mempunyai kaitan dengan masalah dan tujuan penelitian (Dewi, 2020).

Nazir (2010) menyatakan bahwa penelitian kepustakaan merupakan teknik dalam mengumpulkan data menggunakan studi penelaahan pada buku, jurnal maupun literatur lainnya yang berhubungan dengan masalah penelitian. Objek penelitian menggunakan model pembelajaran jarak jauh atau daring sebagai suatu model pembelajaran yang harus digunakan pada masa pandemik Covid 19.

Pengumpulan data ini dilakukan dengan melakukan proses pencarian melalui Google Schoolar, Google Book, dan website. Pengunaan metode ini bertujuan untuk menganalisis berbagai model pembelajaran daring pada siswa khususnya siswa SMK pada materi konsep getaran dan gelombang sebagai alternatif pembelajaran pada masa pandemi covid 19.

\section{HASIL DAN PEMBAHASAN}

Pemerintah melalui Kementerian Pendidikan, Kebudayaan, Riset dan Teknologi mengeluarkan sebuah kebijakan yaitu model pembelajaran daring dalam rangka mencegah penularan Covid 19. Hal ini berdasarkan Undang-Undang Kekarantinaan Kesehatan Pasal 59 Ayat 3 Tahun 2020 yang menyebutkan bahwa pembatasan sosial berskala besar paling sedikit mencangkup penghentian aktivitas sekolah dan tempat kerja, pembatasan kegiatan keagamaan, serta kegiatan pada tempat umum. Pembelajaran yang biasanya dilakukan secara tatap muka di sekolah dihentikan pada Maret 2020 hingga waktu yang belum ditentukan. Mulai saat itu pembelajaran tatap muka berganti dengan pembelajaran tanpa tatap muka yang disebut dengan pembelajaran daring atau e-learning.
Pembelajaran daring merupakan suatu pembelajaran jarak jauh yang dapat dilakukan dengan bantuan teknologi dan internet. Akan tetapi pembelajaran daring hanya dapat berjalan jika memiliki sarana dan prasarana yang menunjang pembelajaran yaitu seperti laptop atau komputer, smartphone, dan jaringan internet. Selain sarana dan prasarana yang memenuhi, akan tetapi kemampuan guru untuk menyesuaikan keadaan juga menjadi faktor yang paling penting.

Hal ini sependapat dengan Wulandari (2018), yang mengatakan jika guru harus fleksibel sehingga harus terus memupuk profesinya untuk dapat melaksanakan tugasnya sesuai kebutuhan siswa yang terus mengikuti perubahan zaman. Ini menunjukkan jika guru sebagai pendidik harus beradaptasi dengan keadaan siswa agar pembelajaran tetap berjalan sebagaimana mestinya. Dengan adanya teknologi digital, guru harus mampu memanfaatkan teknologi tersebut sebagai penunjang kegiatan belajar mengajar. Berdasarkan hasil survei yang dilakukan Badan Pusat Statistik (2020) yang menghasilkan angka presentase masyarakat yang menggunakan smartphone mencapai $63,53 \%$ dan pengguna internet yang mengalami peningkatan menjadi $47,69 \%$, hal ini akan terus meningkat sepanjang tahun yang diperkirakan pada tahun 2025 penguna internet di Indonesia mencapai $89 \%$.

Data tersebut sesuai dengan hasil telaah yang dilakukan menunjukkan bahwa meskipun ada siswa yang tidak mempunyai laptop atau komputer, akan tetapi sebagian besar siswa mempunyai smartphone. Smartphone menjadi perangkat yang paling banyak digunakan siswa untuk melakukan pembelajaran daring agar dapat mengakses internet sehingga siswa bisa mengikuti kegiatan belajar mengajar yang dilakukan melalui video conferrence maupun layanan 
aplikasi lainnya (Handarini \& Wulandari, 2020).

Teknologi digital yang terus berkembang setiap tahunnya membuat guru harus terus beradaptasi mengikuti perkembangan karena dunia pendidikan akan terus ditantang untuk menyesuaikan dengan perkembangan zaman. Guru yang akan bertahan adalah yang mampu beradaptasi dengan berbagai perkembangan zaman melalui berbagai inovasi model pembelajaran. Ini berlaku untuk semua guru pada setiap jenjang pendidikan, karena setiap jenjang pendidikan mempunyai tantangan yang berbeda-beda. Termasuk guru SMK yang harus menyesuaikan kegiatan keterampilan atau praktik siswa diubah melalui pembelajaran daring. Hal ini dibuktikan oleh (Tridiana \& Rizal, 2020) bahwa untuk menghasilkan siswa yang kompetitif dan kreatid untuk persaingan dunia kerja maka guru SMK harus mampu menguasai teknologi informasi.

Hasil beberapa penelitian pada siswa SMK di Indonesia saat pembelajaran daring menunjukkan jika siswa kurang siap dengan pembelajaran daring karena dilakukan secara mendadak tanpa melakukan arahan terlebih dahulu. Hal lainnya juga disebabkan karena guru mata pelajaran yang memberikan tugas yang belum terselesaikan tanpa mengetahui keadaan siswa di rumah. Umumnya siswa dirumah mempunyai berbagai macam kendala seperti kondisi rumah yang tidak kondusif untuk belajar ataupun harus melakukan pekerjaan rumah untuk membantu orang tua. Maka sangat penting bagi guru untuk mengetahui karakteristik siswa sehingga dapat menerapkan strategi pembelajaran yang tepat agar siswa mampu memahami materi secara tepat.

Berdasarkan hasil penelitian yang dilakukan oleh Anwar et al., (2017) menunjukkan bahwa pembelajaran daring pada mata pelajaran Fisika terutama pada konsep getaran dan gelombang pada siswa khususnya siswa SMK belum dapat memberikan kesempatan dan memotivasi siswa agar dapat mengembangkan kreatifitas. Kurangnya media yang mendukung dalam mengarahkan siswa pada fenomena getaran dan gelombang menjadi salah satu penyebabnya. Selain itu seharusnya materi getaran dan gelombang lebih menekankan pada pembelajaran yang real dan kontekstual agar dapat mengkontruksi konsep materi.

Hasil penelitian lain disampaikan oleh Sundari (2020) yang melakukan pembelajaran daring melalui media whatsapp group dan google classroom pada materi konsep getaran dan gelombang yang menunjukkan jika pembelajaran daring yang di desain dengan baik akan menunjang keberhasilan pembelajaran. Desain pembelajaran yaitu terdiri dari tujuan pembelajaran yang jelas, kualitas konten, strategi pembelajaran, psikologi dan evaluasi pembelajaran. Akan tetapi pada pelaksanaannya masih terdapat kekurangan yaitu tidak semua siswa berperan aktif dalam proses pembelajaran jika pendidik tidak bertanya langsung kepada satu per satu siswa untuk mendapatkan respon jawaban.

Penelitian lain disampaikan oleh (Dewa et al., 2020) yang mengungkapkan bahwa pembelajaran daring pada mata pelajaran Fisika dengan bantuan media dapat meningkatkan minat siswa pada pembelajaran sehingga hasil belajar siswa mengalami peningkatan. Agar pembelajaran daring menciptakan suasana yang menyenangkan maka dapat dilakukan dengan beberapa cara yaitu harus memperhatikan pengelolaan waktu dan karakteristik siswa, melatih siswa agar aktif selama proses pembelajaran, dan memberikan latihan soal kepada siswa selama proses pembelajaran.

Konsep getaran dan gelombang ini, banyak siswa yang menemui kendala ketika 
pembelajaran daring yang diakibatkan keterbatasan siswa dalam melakukan praktik dirumah karena materi yang membutuhkan pemahaman lebih. Sehingga guru harus mampu membuat suatu strategi yang mampu membuat siswa memahami materi meskipun melalui pembelajaran dari.

Strategi yang tepat model pembelajaran daring yang diterapkan pada konsep getaran dan gelombang dapat menciptakan kemandirian pada siswa dikarenakan berfokus pada student centered. Pada saat kegiatan belajar mengajar via online inilah siswa dapat mengemukakan gagasan maupun idenya dengan baik tanpa rasa malu. Akan tetapi banyak penelitian yang menyebutkan jika tidak semua siswa dapat mengakses pembelajaran ini, banyak siswa yang akhirnya tidak melakukan pembelajaran dikarenakan keterbatasan akses internet di daerahnya hingga akhirnya guru yang mendatangi langsung rumahrumah siswa untuk melakukan pembelajaran langsung.

Indonesia yang terdiri dari berbagai macam pulau membuat akses internet sulit menjangkau semua kawasan. Ini mengakibatkan beberapa daerah masih sulit akan sinyal internet dan jika pembelajaran terus dilakukan secara daring berarti sama saja siswa menghentikan pembelajarannya sampai waktu yang belum ditentukan. Dalam pembelajaran daring tidak semua wilayah mempunyai jaringan internet yang memadai sehingga menimbulkan kesulitan akses Hasanah et al., (2020). Hal ini berdampak pada sulitnya siswa dalam melakukan pembelajaran daring dan biaya juga menjadi faktor lainnya dikarenakan siswa akan mengeluarkan biaya untuk membeli kuota internet digunakan sebagai akses pembelajaran yang sering kali membutuhkan banyak kuota akibat kegiatan belajar mengajar melalui video conference.

Dampak yang tidak baik juga ditimbulkan akibat penggunaan smartphone terlalu sering yaitu menimbulkan kecanduan dan juga mata minus akibat sering menatap layar. Beberapa penelitian menunjukkan jika siswa SMK lebih memilih untuk melakukan pembelajaran secara tatap muka di sekolah dibandingkan dengan pembelajaran daring. Hal ini dikarenakan dalam pembelajaran tatap muka siswa SMK lebih nyaman melakukan interaksi dengan teman sebayanya maupun dengan guru secara langsung dan dapat melakukan keterampilan melalui praktik sehingga konsep materi yang disampaikan oleh guru dapat langsung diterapkan.

\section{SIMPULAN DAN SARAN}

Pada sektor pendidikan pemerintah mengeluarkan suatu kebijakan yaitu pembelajaran daring sebagai salah satu upaya menekan penularan Covid 19. Berdasarkan hasil telaah pustaka yang dilakukan menunjukkan bahwa siswa SMK yang melakukan pembelajaran daring memerlukan sarana dan prasarana yang memadai seperti jaringan internet dan perangkat mobile. Tetapi tidak semua siswa dibekali dengan fasilitas yang memadai sehingga masih ada siswa yang tidak melakukan pembelajaran daring. Model pembelajaran daring yang diterapkan pada konsep getaran dan gelombang membuat siswa menjadi mandiri karena berfokus pada student centered. Dengan model tersebut, siswa menjadi lebih mandiri dengan mengemukakan lebih banyak gagasan dan ide. Akan tetapi, pembelajaran daring belum mampu sepenuhnya mengembangkan kreatifitas siswa karena membutuhkan media yang secara langsung dapat memotivasi siswa.

\section{DAFTAR PUSTAKA}

Anwar, K., Rusdiana, D., Kaniawati, I., \& Viridi, S. 2017. Profil Pembelajaran 
dan Pengajaran Fisika (GetaranGelombang) yang Sesuai Abad 21. Paedagoria Jurnal Pendidikan, Penelitian Dan Pengembangan. 8(2), $16-23$.

Badan Pusat Statistik. 2020. Statistik Telekomunikasi Indonesia 2019. https://www.bps.go.id/publication/202 0/12/02/be999725b7aeee62d84c6660/s tatistik-telekomunikasi-indonesia2019.html

Covid19.go.id. 2021. Data Sebaran Covid19 di Indonesia. https://covid19.go.id/

Dewa, E., Mukin, M. U. J., \& Pandango, O. 2020. Pengaruh Pembelajaran Daring Berbantuan Laboraturium Virtual Terhadap Minat dan Hasil Belajar Kognitif Fisika. Jurnal Riset Teknologi dan Inovasi Pendidikan. 3(2):351-359.

Dewi, W. A. F. 2020. Dampak Covid-19 terhadap Implementasi Pembelajaran Daring di Sekolah Dasar. Edukatif: Jurnal Ilmu Pendidikan. 1(1):55-61.

Eggen, P., \& Kauchak, D. 2012. Strategi dan Model Pembelajaran: Mengajarkan Konten dan Keterampilan Berpikir (Satrio (ed.)). Indeks.

Handarini, O. I., \& Wulandari, S. S. (2020). Pembelajaran Daring Sebagai Upaya Study From Home (SFH) Selama Pandemi Covid-19. Jurnal Pendidikan Administrasi Perkantoran, 8(2), 496503.

Hasanah, A., Lestari, A. S., Rahman, A. Y., \& Danil, Y. I. 2020. Analisis Aktivitas Belajar Daring Mahasiswa Pada Pandemi Covid-19. Jurnal Pendidikan. 1(1):1-9.

Kasidi, Satyarini, M. D., \& Widayati, S. 2020. Analisis Model Pembelajaran Daring di Masa Pandemi Covid-19. Journal of Economic Education and Entrepreneurship. 1(2):56-65.

Moleong, L. 2005. Metodologi Penelitian Kualitatif. PT. Remaja Rosdakarya.
Nazir, M. 2010. Metode Penelitian. Jakarta: Ghalia Indonesia.

Noviansyah, W., \& Mujiono, C. 2021. Analisis Kesiapan dan Hambatan Siswa SMK dalam Menghadapi Pembelajaran Daring di Masa Pandemi. Jurnal Studi Guru Dan Pembelajaran. 4(1):82-88.

Pramuda, A., \& Anggraeni, L. 2016. Pengembangan Media Pembelajaran Getaran dan Gelombang Berbasis Holografi. Jurnal Pendidikan Informatika Dan Sains. 5(2):157-173.

Ramanta, D., \& Widayanti, F. D. 2020. Pembelajaran Daring di Sekolah Menengah Kejuruan Putra Indonesia Malang pada Masa Pandemi Covid-19. Prosiding Seminar Bimbingan Dan Konseling.

Sofyana, \& Abdul. 2019. Pembelajaran Daring Kombinasi Berbasis Whatsapp Pada Kelas Karyawan Prodi Teknik Informatika Universitas PGRI Madiun. Jurnal Nasional Pendidikan Teknik Informatika. 8(2): 81-86.

Suharno, S. E., \& Widiastuti, I. (2017). Pengembangan Standar Pelaksanaan Praktik Kerja Industri (Prakerin) Siswa SMK Program Keahlian Teknik Pemesinan di Wilayah Surakarta. Jurnal Ilmiah Pendidikan Teknik Kejuruan. 10(1): 22-30.

Sundari. (2020). Pemanfaatan Softfile Bahan Ajar Bermuatan Kearifan Lokal Pada Materi Getaran, Gelombang dan Bunyi Selama PJJ. Jurnal Profesi Keguruan. 6(2):174-181.

Tridiana, R., \& Rizal, F. (2020). Keterampilan Guru Abad 21 di Sekolah Menengah Kejuruan (SMK). Jurnal Ilmiah Pendidikan Dan Pembelajaran. 4(2):221-231.

WHO. (2021). Covid-19 Coronavirus Pandemic. 
https://www.worldometers.info/corona virus/

Wulandari. (2018). Peningkatan Kompetensi Profesional Guru Kewirausahaan melalui Lesson Study Berbasis Pantai dan Laut. Jurnal Pendidikan Edutama. $5(2)$. 